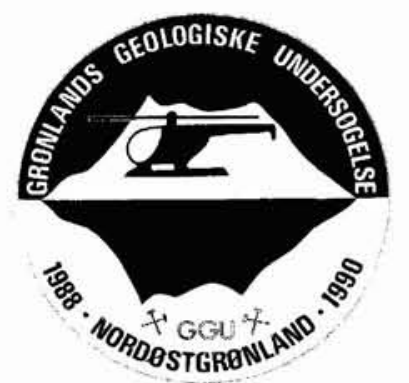

\title{
Structure of the Storstrømmen shear zone, eastern Hertugen af Orléans Land, North-East Greenland
}

\author{
R. A. Strachan and I. R. Tribe
}

\begin{abstract}
The Storstrømmen shear zone is a NNE-trending belt of steep, heterogeneously deformed gneisses and mylonites, at least $8 \mathrm{~km}$ wide, which transects the basement gneiss complexes of the Caledonian fold belt between Dronning Louise Land and Hertugen af Orléans Land. Shear criteria indicate a consistent sinistral sense of displacement parallel to a gently-plunging L-S fabric. Mineral assemblages and fabrics within the mylonites indicate that mylonitisation was initiated under low amphibolite facies conditions and continued within the greenschist facies. The shear zone is reworked by late, steep brittle faults which are associated with cataclasis and local metamorphic retrogression.
\end{abstract}

R. A. S. \& I. R. T., Geology \& Cartography Division, School of Construction \& Earth Sciences, Oxford Brookes University, Oxford OX3 OBP, U.K.

The Storstrømmen shear zone (SSZ) is a NNE-trending belt of steep, heterogeneously deformed gneisses and mylonites, at least $8 \mathrm{~km}$ wide, which transects the basement gneiss complexes of the Caledonian fold belt in North-East Greenland (Fig. 1). The SSZ has been recognised along the eastern margin of Dronning Louise Land (Friderichsen et al., 1990), in north-west Dove Bugt (Chadwick \& Friend, 1994) and in eastern Hertugen af Orléans Land (Fig. 1; Strachan et al., 1991). Recent reconnaissance mapping suggests that it is also present further north in eastern Kronprins Christian Land (Jepsen et al., 1994). The SSZ therefore appears to have a minimum along-strike length of $500 \mathrm{~km}$. This paper summarises the structural geometry and kinematic evolution of the SSZ in eastern Hertugen af Orléans Land, and briefly considers the implications of this data for regional tectonic models.

\section{General geology}

Most of Hertugen af Orléans Land (Fig. 1) is underlain by an orthogneiss complex which lies structurally above the Caledonian marginal thrust zone (Strachan et al., 1991). The gneiss complex mainly comprises a heterogeneous series of variably banded, migmatitic dioritictonalitic-granodioritic orthogneisses. These typically display an amphibolite facies metamorphic assemblage of hornblende + biotite + feldspars + quartz + garnet. The gneisses contain minor inclusions of older mafic to ultramafic material, which mainly comprise hornblende and garnet with minor pyroxene. Gneissosity is defined by compositional layering and preferred orientation of elongate minerals. The gneisses are intruded by granitic and augen gneisses and sheets of metadolerite.

The SSZ occupies a low-lying region located along the eastern margin of Hertugen af Orléans Land (Figs 1,2). The contact between the orthogneisses to the west and the SSZ is mainly defined by late brittle faults. The basement gneisses show increasing signs of superimposed ductile and brittle deformation over a distance of $c .300 \mathrm{~m}$ as the shear zone is approached, and related minor shear zones are developed up to $2-3 \mathrm{~km}$ west of the SSZ (Fig. 2). The SSZ comprises a series of steep mylonite zones which anastomose around belts and augen of lower tectonic strain, within which the gneissic protoliths are variably reworked. Lenses and pods of heterogeneously mylonitised metagabbro occur within the gneisses south of Sanddal (Fig. 2). Brittle faults are concentrated along the SSZ, and are commonly marked by prominent zones of cataclasite, up to $50 \mathrm{~m}$ across.

There is a concentration within and proximal to the SSZ of a variety of minor intrusions. In south Sønderland and Søndre Mellemland (Fig. 2), the earliest intrusions are swarms of pink, granitic sheets, up to $2 \mathrm{~m}$ thick, which carry a penetrative mylonitic fabric. These are apparently post-dated by emplacement of white-grey leucocratic granite intrusions, which are also mylonitised (Fig. 2). Syn- to late-kinematic, variably foliated granitoid and felsic pegmatites are discordant to the mylonite fabric and earlier intrusions. The spatial association of these intrusions with the SSZ may indicate that they were emplaced syn-kinematically during ductile shear. 


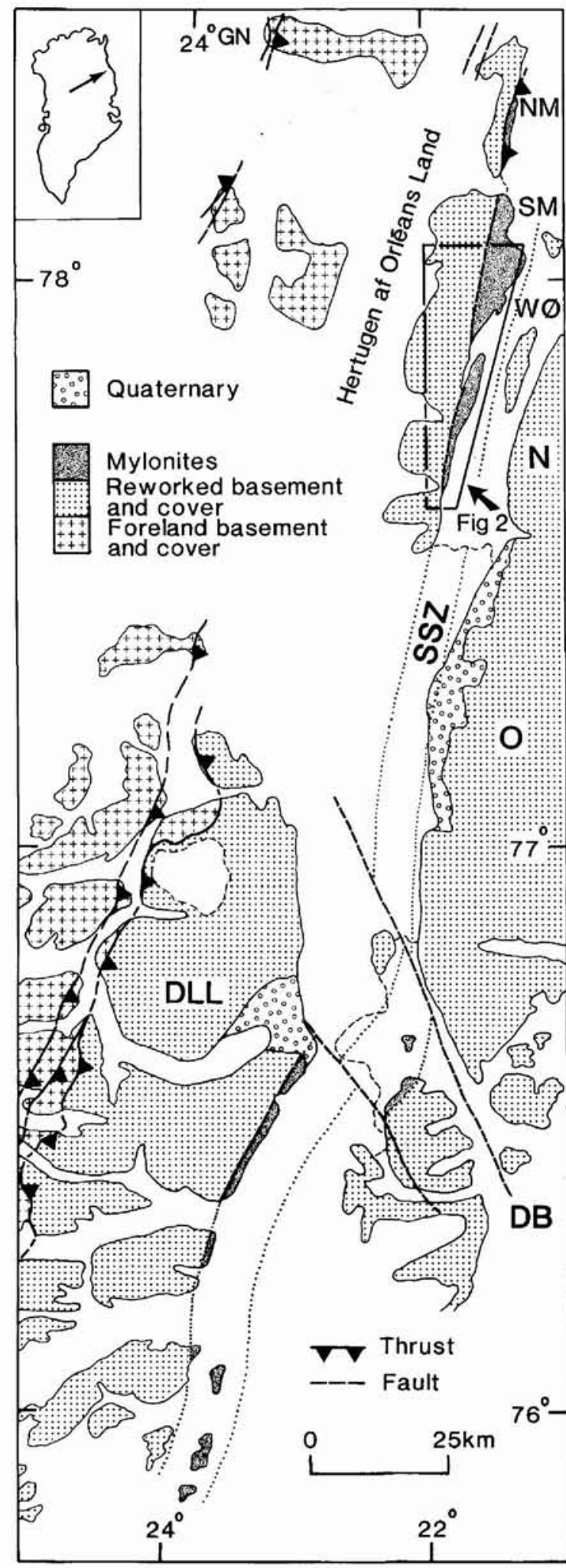

Fig. 1. Geological map showing extent of Storstrømmen shear zone. DLL, Dronning Louise Land; DB, Dove Bugt; N, Nordmarken; GN, Garde Nunatak; NM, Nørre Mellemland; O, Okselandet; Wø, Weinschenk $\varnothing$; SSZ, Storstrømmen shear zone.
Basement gneisses observed east of the SSZ, on Weinschenk $\varnothing$ (Fig. 1), are mainly nebulitic grey orthogneisses with numerous minor inclusions of garnetpyroxene bearing mafic material.

\section{Structural analysis}

West of the Storstrommen shear zone

All components of the orthogneiss complex, except occasional late pegmatites and granites, are affected by two major phases of deformation (Table 1). The earliest of these is represented by mesoscopic isoclinal sheath folds which are curvilinear about a NNE-trending mineral and stretching lineation. Shear criteria, including rotated porphyroclasts and shear pods, indicate that these folds formed in response to a general northward direction of transport parallel to this lineation. Deformation was accompanied by widespread metamorphic recrystallisation and formation of axial surface fabrics. These folds are thought to have had a recumbent attitude prior to formation of a series of major, close to open upright folds which trend NE to NNE, broadly parallel with earlier lineations and fold axes (Fig. 2). Fold hinges plunge gently to the SW and NE (Fig. 2). Recrystallisation of hornblende around these later fold hinges implies that folding was probably accompanied by amphibolite facies metamorphism.

\section{Storstrømmen shear zone}

The most prominent structure is a steep, NNE-trending mylonitic L-S fabric which is $c .10^{\circ}$ oblique to the regional fabric elements west of the SSZ. The linear component is gently plunging, mainly towards the SSW (Fig. 2). A sinistral sense of displacement parallel to the lineation may be deduced from a variety of shear criteria. These include rotated porphyroclasts (sigma and delta types), shear pods, C-S fabrics and mesoscopic shear zones. Although the scale at which mapping was carried out generally precluded detailed analysis, it is possible to delineate several different rock types within the SSZ (Fig. 2). These all carry the same L-S fabric and associated shear criteria, and are distinguished on the basis of the degree of modification of protolith fabrics and mineralogy. Terminology used here follows that of Sibson (1977).

(1) Protomylonitic gneisses (Fig. 3A). These retain a gneissic compositional banding similar in character to that of protolith gneisses west of the SSZ, and display limited microscopic evidence for grain size reduction and dynamic recrystallisation.

(2) Mylonitic gneisses (Fig. 3B). These are characterised by marked parallelism and attenuation of gneissic banding, associated with pervasive grain size reduction and dynamic recrystallisation. 


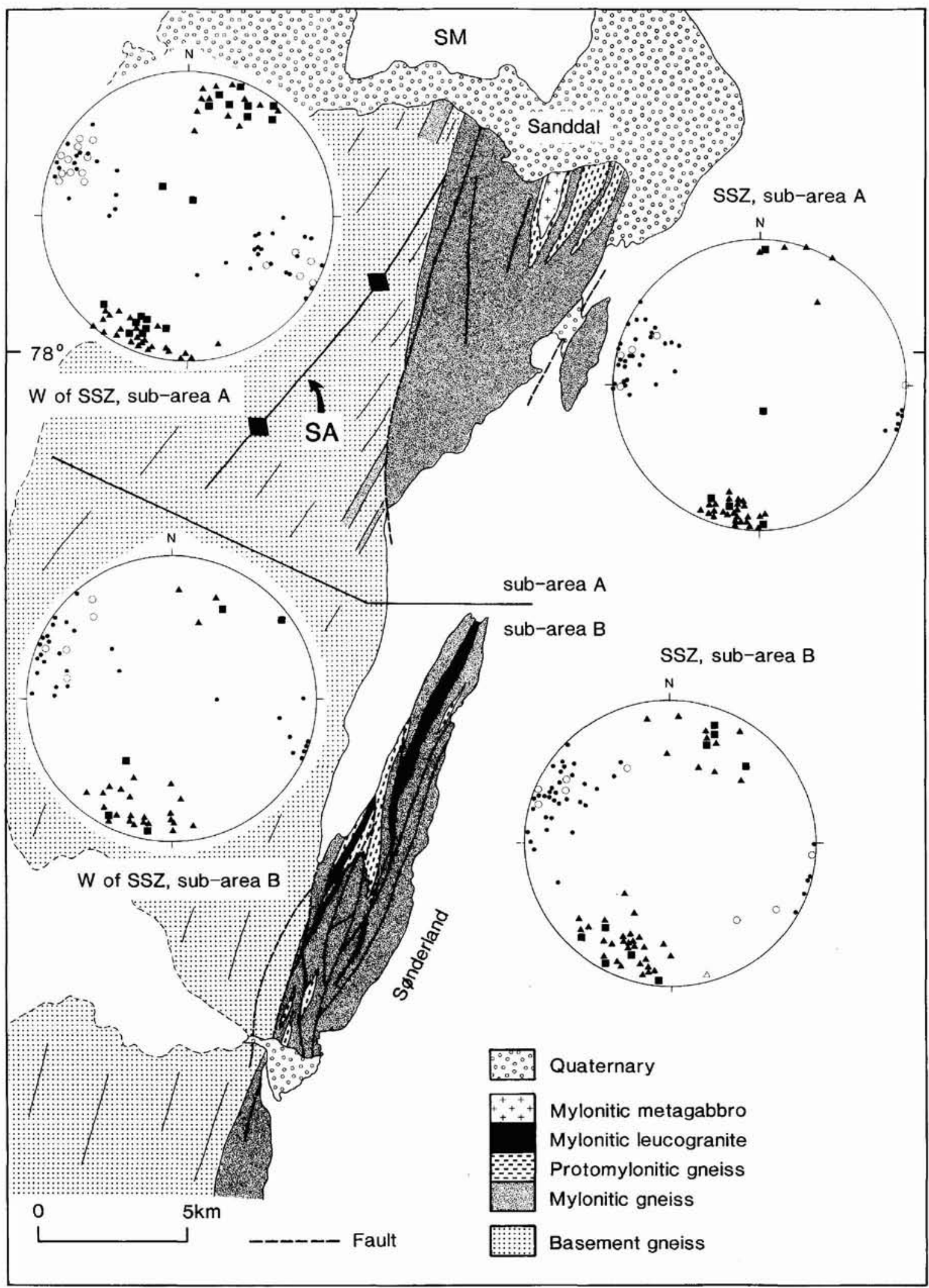

Fig. 2. Geological map of eastern Hertugen af Orléans Land (location shown in Fig. 1) showing generalised distribution of rock types, together with lower hemisphere, equal area projections of structural data. Triangles, mineral and stretching lineations; squares, fold axes; dots, poles to foliation; open circles, poles to fold axial surfaces. SSZ, Storstrømmen shear zone; SA, Sønderland antiform; SM, Søndre Mellemland. 

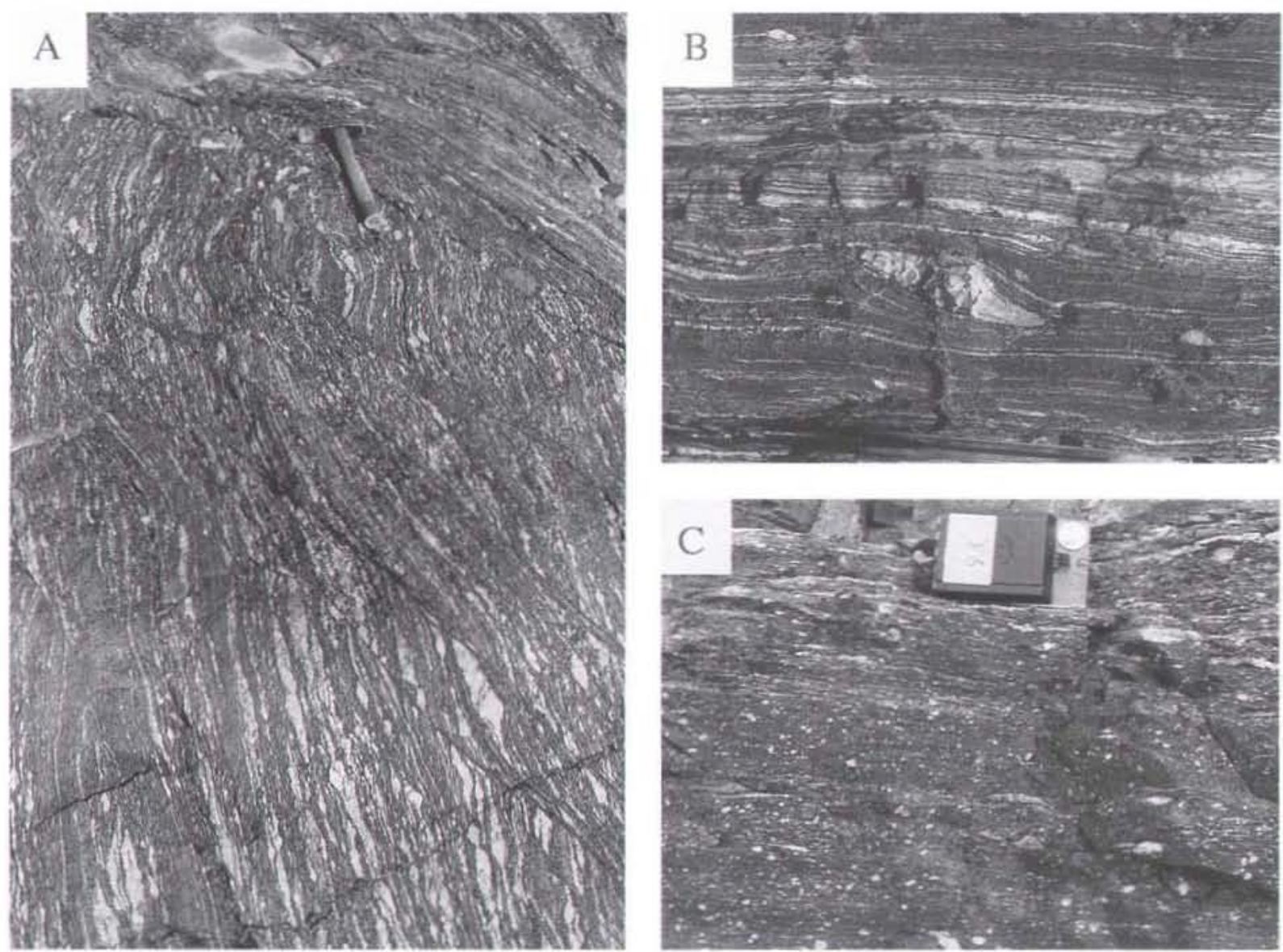

Fig. 3. A: Protomylonitic gneiss of the SSZ, showing sinistral S-C fabrics cut by sinistral C' surfaces, south-east Swnderland. B: Mylonitic grey gneiss of the SSZ, showing sinistral shear (sigma-type porphyroclast). Sondre Mellemland.

C: Ultramylonitic gneiss of the SSZ, Norre Mellemland.

(3) Ultramylonitic gneisses (Fig. 3C). These represent the results of extreme grain size reduction; original gneissic fabrics may now only be discernable as a faint millimetre-centimetre colour banding. The ultramylonites are generally dark-coloured rocks with a flinty and highly fractured aspect. Mappable belts of ultramylonite up to $50 \mathrm{~m}$ wide are present in south Sønderland.

The SSZ displays a complex fold history (Table 1). Rare, intrafolial isoclinal folds deform the mylonite fabric and may be curvilinear about the mylonitic lineation. These are interpreted as sheath folds, formed during mylonitisation (Carreras et al., 1977; Evans \& White, 1984). There is local evidence for at least two sets of these folds, possibly suggesting progressive and continuous folding during shearing. Similar folds have been recorded within the SSZ in eastern Dronning Louise Land (Fig. 1; Holdsworth \& Strachan, 1991).

The most common folds within the SSZ are upright to moderately-inclined, open to tight folds which fold the mylonite fabric (Table 1). Fold hinges are mostly rounded, cylindrical structures which are collinear with the mylonite lineation. In Sønderland and central Søndre Mellemland, fold axial surfaces are mostly upright and the folds display complex vergence. In Nørre Mellemland, axial surfaces are mainly moderately inclined to the ESE, and folds consistently verge to the WNW. In contrast to the earlier set of folds described above, there is no indication that these folds formed during mylonitisation. They are interpreted to record a period of approximately orthogonal compression normal to the SSZ, following sinistral displacements. Similar folding of SSZ mylonites by NW-vergent folds, following sinistral displacements, has been recorded in north-west Dove Bugt (Fig. I; Chadwick \& Friend, 1991, 1994). Folding of the SSZ is interpreted as an out-of-sequence event relative to the timing of formation of the marginal thrust belt and related folds to the west (Dallmeyer et al., 1994). 
Table 1. Structural and metamorphic events in Hertugen af Orléans Land

Late semi-ductile to brittle fault reworking.

Upright to moderately-inclined, open to tight folds of mylonite fabric, associated in north with west-directed thrusting of SSZ mylonites onto basement gneisses.

Continuation of strike-slip displacements, greenschist facies metamorphism.

Sinistral strike-slip displacements, amphibolite facies

Close to upright folds, trend NE to NNE. Amphibolite facies metamorphism. Polyphase generation of syn-mylonitisation folds. metamorphism.

Recumbent isoclinal sheath folds, curvilinear about NNE-trending lineation.

Amphibolite facies metamorphism.

?

\section{Brittle faulting}

There is a concentration along the SSZ of late, brittle faults (Fig. 2). These are mostly steep, NNE-SSW to $\mathrm{N}-\mathrm{S}$ trending structures which are generally subparallel to the regional foliation trend. Cataclastic rocks located along these faults vary from coarse, angular breccias to fine-grained fault gouge, and are commonly associated with epidote and quartz veining. Late retrogressive chlorite coats joint surfaces. Slickensides on fault planes in the area south of Sanddal mostly pitch steeply, indicating a dip-slip sense of displacement, although whether this was reverse or normal is impossible to establish given the lack of offset markers and other unambiguous kinematic indicators. In south Sønderland, a sinistral sense of displacement is indicated along several faults which define large-scale (hundreds of metres) shear band structures.

\section{Relative timing of regional folding and sinistral displacements}

The large-scale obliquity between the SSZ and regional folds and fabrics to the west (Fig. 2) requires further analysis. It is likely that at least locally this results from west-directed reverse faulting along the margin of the SSZ. In Nørre Mellemland (Fig. 1), SSZ mylonites have been thrust westwards onto basement gneisses; this is inferred to have accompanied late west-vergent folding of the mylonites (Table 1; Strachan et al., 1991).

In Sønderland and Søndre Mellemland (Fig. 1), structural relationships are less straightforward. In south Sønderland, regional structures and the SSZ are approximately parallel (Fig. 2). Obliquity appears to progres- sively increase northwards. South of Sanddal, both the regional foliation and the axial trace of the regional Sønderland antiform curve smoothly anticlockwise into parallelism with the SSZ (Fig. 2). Steep mylonite zones with sinistral senses of shear are developed on both sides of the Sønderland antiform (Fig. 2). The mylonites are mineralogically and texturally identical to those of the SSZ. They are interpreted as ductile P shear zones (Sylvester, 1988) which formed at the same time as the SSZ. The precise time relationship between upright folding and sinistral displacements is unclear. Field relations could be interpreted as indicating that the SSZ and associated shear zones were superimposed on the basement gneisses after formation of the Sønderland antiform. An equally valid alternative model is that upright folding occurred during sinistral displacements along the SSZ. The clockwise orientation of the Sønderland antiform in relation to the sinistral SSZ is consistent with a transpressive model for the coeval development of regional folds and shear zones (cf. Sylvester, 1988).

\section{Mylonite mineralogy and microstructures Mineralogy}

The following analysis is based on observations from 52 samples of mylonites from the SSZ and related shear zones. Mylonite mineralogy is dominated by quartz and feldspars, which comprise $45-90 \%$ of most samples. Feldspars are mainly plagioclase; where it is possible to establish compositions these are typically oligoclase $\left(\mathrm{An}_{20-28}\right)$. Augen and matrix are similar in composition. Amphibole has been identified in nine samples of mylonitic amphibolite and mylonite derived from mafic gneiss. 


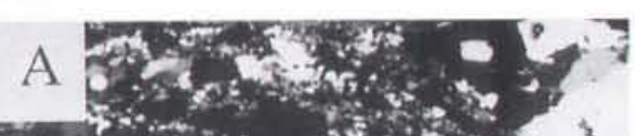

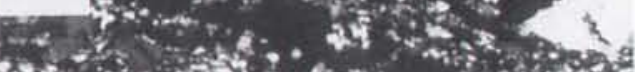

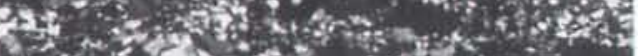

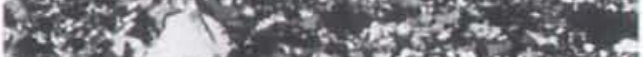

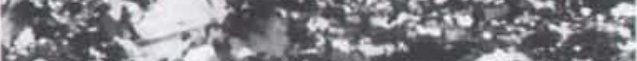

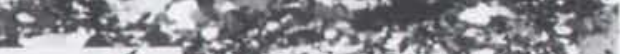

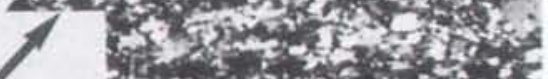

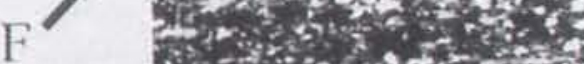
6.

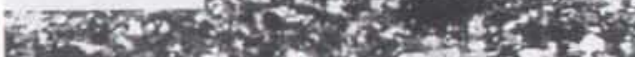

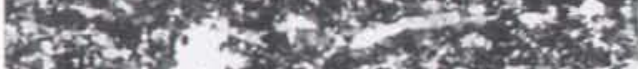
7. F.

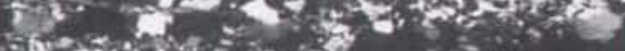

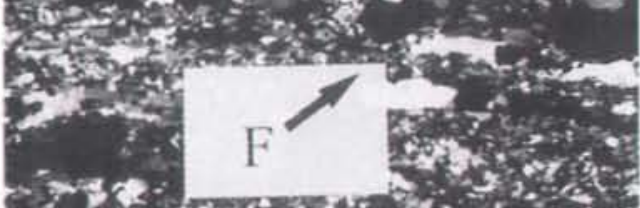

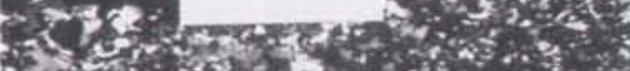

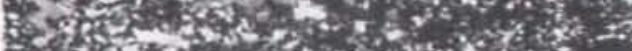

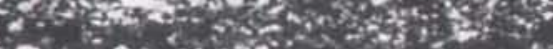

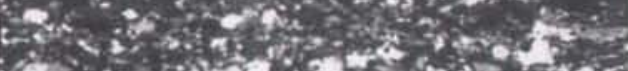
La

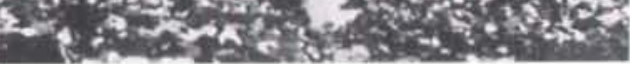

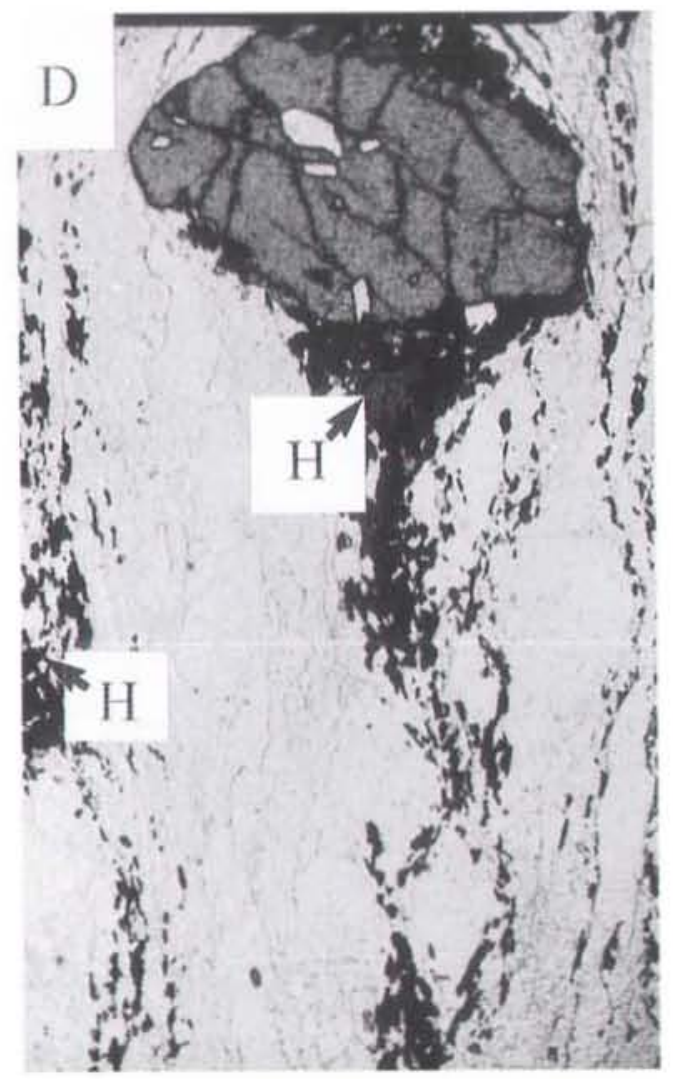

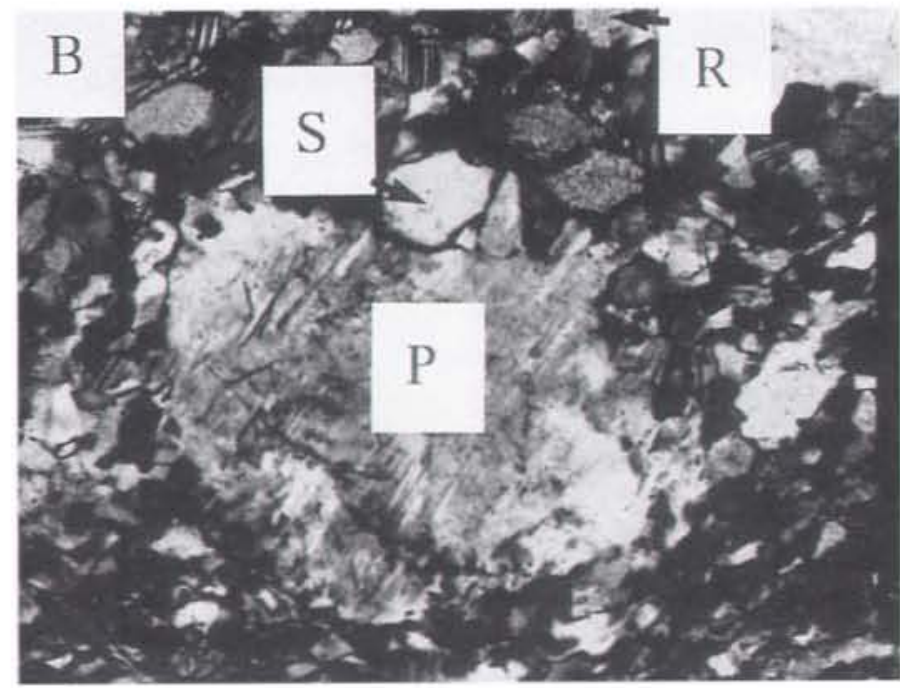

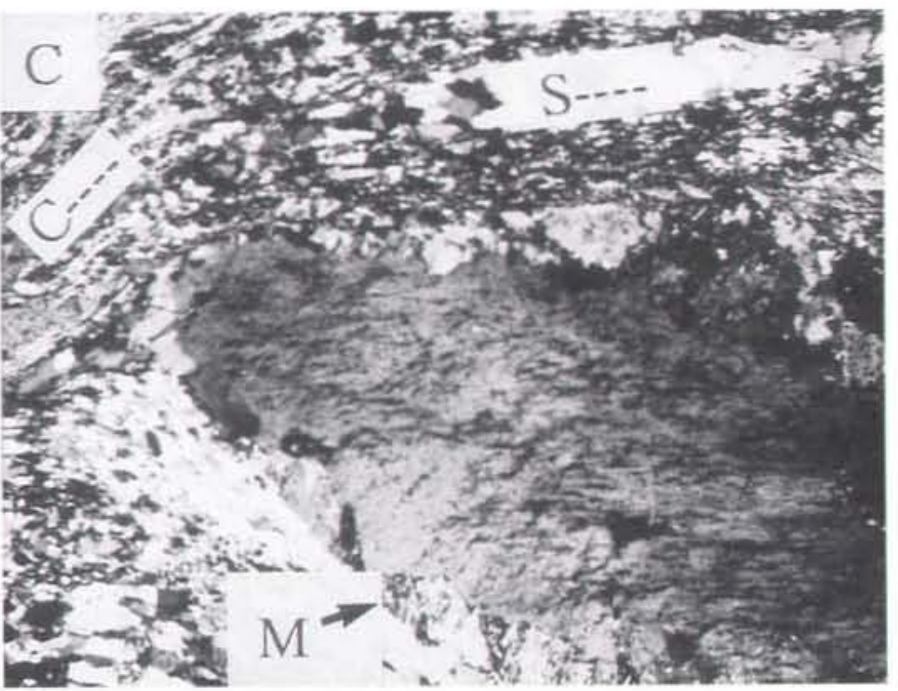

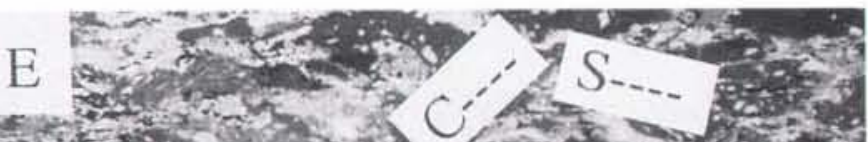

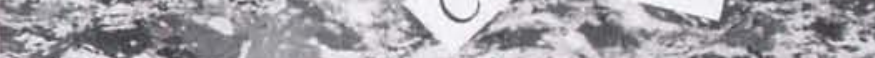

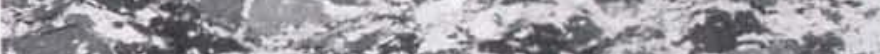

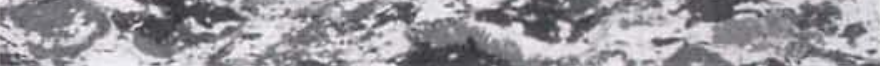

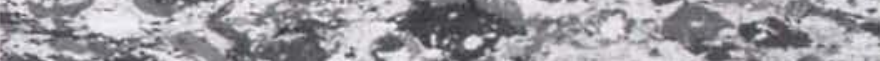

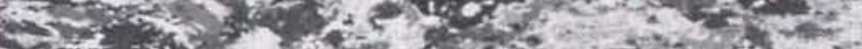

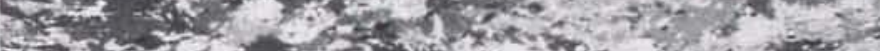

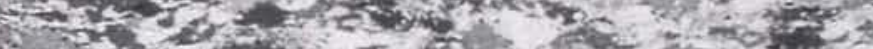

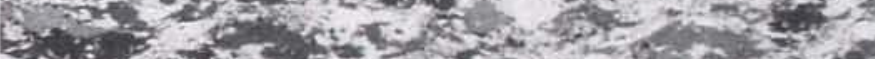

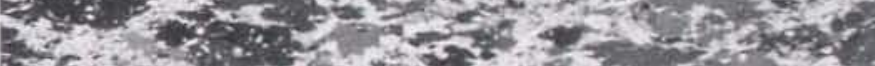

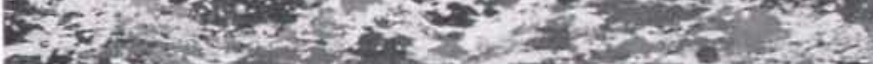

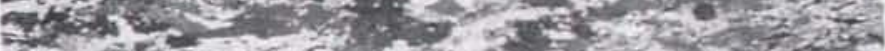

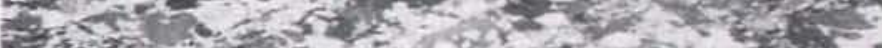

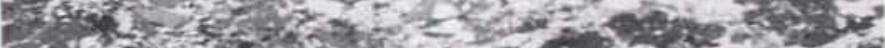

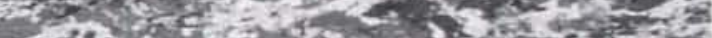

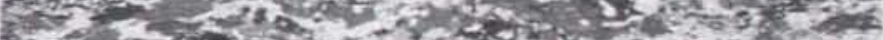

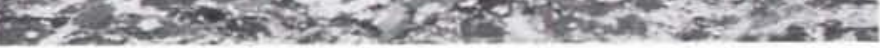


In eight of these samples, hornblendic amphibole (mineral chemistry analytical data obtainable from authors) occurs as recrystallised porphyroblasts aligned parallel to the mylonitic L-S fabric; in one sample of ultramylonite it occurs as relict augen wrapped by the mylonite fabric. Garnet occurs in two samples. Recrystallised grains of aligned brown or green biotite are ubiquitous, and occur both intergrown with, and as a replacement of, amphibole. Biotite forms the major part of the fine-grained matrix characteristic of the ultramylonites. Epidote or clinozoisite commonly occur as porphyroblasts in mylonites derived from mafic protoliths. Muscovite is commonly present in mylonites derived from granitoid protoliths. Minor amounts of chlorite (mainly from the retrogression of biotite), opaque minerals, titanite and zircon occur in most samples.

\section{Main mylonite fabric}

In most samples of protomylonite and mylonite, fabrics are mainly defined by the alignment of recrystallised bands of mica, quartz and feldspar enhanced by subparallel amphiboles and quartz-feldspar augen.

Quartz forms elongate ribbons which are characterised by aggregates of approximately equant strain-free grains with common triple junctions (type 2 and 3 ribbons of Boullier \& Bouchez, 1978; Fig. 4A). These features imply that the quartz has almost completely recovered and recrystallised following ductile deformation.

Alkali and plagioclase feldspar textures are also dominated by ductile deformation processes with only very local evidence for brittle deformation mechanisms. "Core and mantle' structures are common, with relict feldspar grains displaying undulose extinction and surrounded by a rim of finer, newly recrystallised grains (Fig. 4B,C). With increasing deformation the proportion of recrystal- lised grains increases and aggregates around relict porphyroblasts are drawn out parallel to the mylonitic foliation. Grain size reduction was apparently achieved by recrystallisation - accommodated dislocation creep (Tullis \& Yund, 1985). Quartz-feldspar myrmekitic intergrowths occasionally occur along the sides of alkalifeldspar grains facing the finite shortening direction (Fig. 4C). These textures are similar to those described by Simpson (1985) and are interpreted as representing myrmekite induced by deformation.

Hornblendic amphiboles mainly occur as porphyroblasts which recrystallised during mylonitisation and are in textural equilibrium with the mylonite fabric. These are usually fresh, unaltered grains which may locally have undergone partial dynamic recrystallisation to finergrained aggregates (Fig. 4D). The new grains formed during mylonitisation are typically of a similar composition to host grains. In four samples of mylonitic gneiss and amphibolite, recrystallised hornblende grains define S- and C-planes (Fig. 4E). These features suggest that hornblendic amphibole was stable during mylonitisation and locally has deformed by ductile deformation mechanisms. In one sample of ultramylonite, relict porphyroclastic augen of hornblende are accompanied by elongate pressure shadows of retrogressive biotite and recrystallised quartz.

Garnet is present in two samples. In one of these (Fig. 4D), garnet occurs as sub-rounded porphyroclasts with pressure tails of recrystallised hornblende, quartz and feldspar. There is no indication that the garnet has recrystallised during mylonitisation. In contrast, in the other sample, elongate garnet porphyroblasts are in parallel alignment and apparent textural equilibrium with the mylonite fabric. These relationships suggest that in this sample garnet recrystallised during mylonitisation.

Biotite and muscovite occur as bands of recrystallised

Fig. 4. A: Blastomylonitic fabric within deformed hornblendic gneiss from the western margin of the SSZ in Sanddal (GGU 347562). Foliation is defined by elongate feldspar aggregates and type 3 quartz ribbons. Feldspar porphyroclasts (F) are mantled by subgrains and new recrystallised grains which are drawn out parallel to the mylonitic foliation. Field of view $13 \mathrm{~mm}$.

B: Plagioclase core and mantle structure within mylonitic gneiss from western margin of the SSZ south of Sanddal (GGU 347524). Relict porphyroclast (P) shows development of subgrains (S) and new recrystallised grains (R) of feldspar around margins. Field of view $1.8 \mathrm{~mm}$.

C: Alkali feldspar porphyroclast within mylonitic granitoid pegmatite from central part of SSZ (prominent peninsula south of Sanddal, Fig. 2) (GGU 347528). Myrmekitic intergrowths (M) are developed along the margins which face the instantaneous shortening direction. C- and S-planes are defined by micas and quartz aggregates. Geometry is similar to that described by Simpson (1985) from amphibolite facies mylonites. Field of view $3.4 \mathrm{~mm}$.

D: Pre-tectonic garnet porphyroclast with pressure shadow of recrystallised hornblendic amphibole $(\mathrm{H}=$ hornblende grains), wrapped by quartz and feldspar aggregates. Mylonitic hornblendic gneiss from the western margin of the SSZ in Sanddal (GGU 347562). Field of view $2 \mathrm{~mm}$.

E: Sinistral C-S fabric defined by hornblendic amphibole. Amphibolite from central part of SSZ, south of Sanddal (GGU 347516 ). Field of view $10 \mathrm{~mm}$. 
grains, and as individual grains and aggregates which may define a pervasive sinistral S-C mylonite fabric. The margins of mica-filled shear bands often smooth the outline of neighbouring quartz ribbons. The recrystallised bands of muscovite can locally be seen to be the result of grain-size reduction of larger muscovite porphyroclasts; these porphyroclasts often represent asymmetric mica fish which define a sinistral sense of shear.

With increasing strain, protomylonites and mylonites pass transitionally into ultramylonites represented by a very fine-grained matrix of dynamically recrystallised quartz, feldspar and micas, with occasional small, rounded augen of relict feldspar.

\section{Late semi-ductile and brittle deformation}

Superimposed on the early mylonite fabric is evidence for localised, semi-ductile deformation. Quartz locally forms ribbons within shear bands which are characterised by undulose extinction and deformation bands with only minor evidence for recrystallisation (cf. type 1 ribbons of Boullier \& Bouchez, 1978). Late- to post-kinematic granite sheets which cross-cut the mylonite fabric at high angles display evidence for localised grain size reduction of quartz and marginal recrystallisation of feldspars. Ductile and semi-ductile fabrics are locally cut by narrow cataclastic bands filled with a low grade assemblage of chlorite + epidote and associated with angular fragments of feldspar. Hornblendic amphibole is locally retrogressed to an actinolitic amphibole alongside the fractures. These features are thought to have formed during late brittle deformation, possibly associated with the brittle faults described earlier.

\section{Metamorphic conditions during mylonitisation}

The texturally stable assemblage of hornblende-oligoclase-K-feldspar-biotite-quartz identified in some mylonites indicates that mylonitisation was initiated under low amphibolite facies conditions (cf. Robinson et al., 1982 for facies terminology). This is consistent with evidence for the ubiquitous ductile deformation of feldspar and local development of strain-induced myrmekite which both strongly suggest that temperatures during mylonitisation were $>450^{\circ} \mathrm{C}$, or above the upper greenschist low amphibolite facies transition (Simpson, 1985; Gapais, 1989). Temperature estimates obtained from coexisting amphibole and plagioclase within a sample of mylonitic amphibolite within the SSZ (GGU 347516) range from $474^{\circ} \mathrm{C}$ to $410^{\circ} \mathrm{C}$ (mean $447^{\circ} \mathrm{C}$; Table 2), using the $\mathrm{NaSi}=\mathrm{CaAl}$ exchange equilibrium of Spear (1980). Analyses used for temperature determinations are give in
Table 2. These are interpreted as minimum temperatures for mylonitisation.

Later growth of epidote and clinozoisite, and the retrogressive replacement of hornblende by biotite or chlorite implies continuation of mylonitisation within the greenschist facies. The textural evidence for localised semiductile-brittle deformation is also consistent with localised reworking of high grade mylonites within the greenschist facies.

\section{Timing of deformation}

In eastern Dronning Louise Land and Hertugen af Orléans Land, regional recumbent folding and subsequent upright folding of basement gneisses west of the SSZ are thought to be Caledonian in age (Friderichsen $e t$ al., 1990; Strachan et al., 1991, 1992). Since the SSZ does not pre-date either of these fold sets (Holdsworth \& Strachan, 1991), it must therefore be a Caledonian struc-

Table 2. Mineral compositions used to calculate temperature estimates from a sample of mylonitic amphibolite within the Storstrommen shear zone (GGU 347516)

\begin{tabular}{|c|c|c|c|c|c|}
\hline $\mathrm{SiO}_{2}$ & 41.51 & 40.93 & 41.86 & 41.13 & 41.38 \\
\hline $\mathrm{TiO}_{2}$ & 0.91 & 1.05 & 0.47 & 0.85 & 0.88 \\
\hline $\mathrm{Al}_{2} \mathrm{O}_{3}$ & 14.55 & 14.88 & 13.96 & 14.35 & 14.13 \\
\hline $\mathrm{FeO}$ & 17.55 & 18.57 & 18.25 & 17.57 & 17.22 \\
\hline $\mathrm{MnO}$ & 0.34 & 0.34 & 0.29 & 0.25 & 0.26 \\
\hline $\mathrm{MgO}$ & 9.20 & 8.32 & 9.03 & 8.90 & 9.25 \\
\hline $\mathrm{CaO}$ & 11.64 & 11.56 & 12.29 & 12.03 & 11.77 \\
\hline $\mathrm{Na}_{2} \mathrm{O}$ & 1.84 & 1.74 & 1.42 & 1.41 & 1.77 \\
\hline $\mathrm{K}_{2} \mathrm{O}$ & 0.87 & 0.92 & 0.55 & 0.79 & 0.79 \\
\hline Total & 98.40 & 98.30 & 98.12 & 97.28 & 97.45 \\
\hline $\mathrm{Si}$ & 6.164 & 6.115 & 6.219 & 6.171 & 6.201 \\
\hline $\mathrm{Al}$-iv & 1.836 & 1.885 & 1.781 & 1.829 & 1.799 \\
\hline Al-vi & 0.710 & 0.735 & 0.663 & 0.708 & 0.696 \\
\hline $\mathrm{Ti}$ & 0.102 & 0.118 & 0.053 & 0.096 & 0.100 \\
\hline $\mathrm{Fe}^{3+}$ & 0.387 & 0.396 & 0.545 & 0.439 & 0.358 \\
\hline $\mathrm{Mg}$ & 2.036 & 1.854 & 2.001 & 1.991 & 2.066 \\
\hline $\mathrm{Fe}$ & 1.793 & 1.925 & 1.723 & 1.766 & 1.800 \\
\hline $\mathrm{Mn}$ & 0.043 & 0.043 & 0.037 & 0.032 & 0.033 \\
\hline $\mathrm{Ca}$ & 1.852 & 1.850 & 1.956 & 1.934 & 1.890 \\
\hline $\mathrm{Na}-\mathrm{M} 4$ & 0.077 & 0.079 & 0.022 & 0.034 & 0.057 \\
\hline $\mathrm{Na}-\mathrm{A}$ & 0.452 & 0.425 & 0.388 & 0.376 & 0.457 \\
\hline K & 0.166 & 0.175 & 0.105 & 0.152 & 0.151 \\
\hline Sum & 15.618 & 15.600 & 15.493 & 15.528 & 15.608 \\
\hline An plag & 0.21 & 0.25 & 0.23 & 0.25 & 0.25 \\
\hline${ }^{\circ} \mathrm{C}$ & 462 & 474 & 410 & 433 & 458 \\
\hline
\end{tabular}

$\mathrm{Fe}^{3-}$ has been calculated using charge balance. The structural formula has been recalculated adopting the intermediate cation sum between 13 (excluding $\mathrm{Ca}, \mathrm{Na}$ and $\mathrm{K}$ ) and 15 (excluding $\mathrm{Na}$ and $\mathrm{K}$ ). 
ture. The precise timing of Caledonian deformation is unclear. U-Pb SHRIMP zircon ages suggest metamorphic events at $445 \pm 10 \mathrm{Ma}$ (late Ordovician) (A.P. Nutman, personal communication) and $404 \pm 6 \mathrm{Ma}$ (late Silurian early Devonian) (Kalsbeek et al., 1993). ${ }^{40} \mathrm{Ar} /{ }^{39} \mathrm{Ar}$ mineral cooling ages obtained from a variety of metamorphic rock units within the Caledonian belt of North-East Greenland mostly range between $c .400 \mathrm{Ma}$ and $c .370$ $\mathrm{Ma}$, and provide an upper limit on regional metamorphism and accompanying deformation (Dallmeyer $e t$ al., 1994). These ages are thought to result from cooling following late Silurian - carly Devonian metamorphism. Muscovite cooling ages of $c .400$ Ma have been obtained from cleaved foreland sediments on Garde Nunatak, and ages of 392-385 Ma have been obtained from mylonites developed along the Caledonian thrust zone in central Dronning Louise Land (Fig. 1). These ages are older than: (1) the majority of hornblende cooling ages (390$380 \mathrm{Ma}$ ) in eastern Dronning Louise Land, Dove Bugt and Nordmarken; and (2) muscovite ages (380-370 Ma) in eastern Dronning Louise Land and the SSZ in Hertugen af Orléans Land. This eastward decrease in cooling ages is interpreted mainly to result from out-of-sequence folding and thrusting (which in Hertugen af Orléans Land clearly post-dates sinistral displacements along the SSZ; Dallmeyer et al., 1994). The mineral cooling ages cannot be used to establish the relative ages of marginal thrusting and sinistral displacements along the SSZ.

A regional deformation chronology must utilise field and microstructural observations, in addition to available geochronological data. On the basis of observations in Dronning Louise Land, Holdsworth \& Strachan (1991) and Strachan et al. (1992) proposed a Caledonian tectonic model which envisaged that oblique marginal thrusting occurred synchronously with sinistral strike-slip displacements along the SSZ. One line of evidence used to support this model relates to the comparable range of lower amphibolite to greenschist facies mylonites in both the SSZ and imbricate thrust zone in Dronning Louise Land. Within these mylonites, lower grade events consistently occur later than higher grade events, which implies that both deformation zones were developed at similar crustal levels, and were active during uplift and erosion.

Microstructural evidence from Hertugen af Orléans Land also indicates that ductile sinistral displacements along this segment of the SSZ occurred under low amphibolite facies conditions $(c .15 \mathrm{~km})$. Mylonitisation continued within the greenschist facies; since both higher and lower grade mylonites apparently carry the same L-S fabric and kinematic indicators, displacements must have been more or less continuous during active uplift and erosion. It seems intuitively unlikely that strike-slip displacements were initiated after, or during the closing stages of, development of the foreland thrust belt, since at this stage all rock units would have been at a relatively high crustal level. The field and microstructural evidence is therefore interpreted to indicate that strike-slip displacements along the SSZ were initiated at mid-crustal levels, broadly coeval with regional thrusting and folding. Similar partitioning of deformation into synchronous orogen-normal and orogen-parallel components has been widely demonstrated from various orogenic belts (e.g. North American Cordillera, Oldow et al., 1989; Himalayas, Mattauer, 1986; Pyrenees, Roure et al., 1989; cf. also review by Oldow et al., 1990).

Acknowledgments. The authors acknowledge discussions with R. E. Holdsworth and R. D. Dallmeyer, and the assistance of K. A. Jones and A. T. Kearsley with, respectively, geothermometry and microprobe analyses.

\section{References}

Boullier, A-M. \& Bouchez, J-L. 1978: Le quartz en rubans dans les mylonites. Bull. geol. Soc. France 7, 253-262.

Carreras, J., Estrada, A. \& White, S.H. 1977: The effects of folding on the c-axis of a quartz mylonite. Tectonophysics $\mathbf{3 9}$, 32-44.

Chadwick, B. \& Friend, C. R. L. 1991: The high-grade gneisses in the south-west of Dove Bugt: an old gneiss complex in a deep part of the Caledonides of North-East Greenland. Rapp. Gronlands geol. Unders. 152, 103-111.

Chadwick, B. \& Friend, C. R. L. 1994: Reaction of Precambrian high-grade gneisses to mid-crustal deformation in western Dove Bugt, North-East Greenland. Rapp. Gronlands geol. Unders. 162 (this volume).

Dallmeyer, R. D., Strachan, R. A. \& Henriksen, N. 1994: ${ }^{40} \mathrm{Ar} /$ ${ }^{39} \mathrm{Ar}$ mineral age record in NE Greenland - implications for tectonic evolution of the North Atlantic Caledonides. J. geol. Soc. Lond. 151, 615-628.

Evans, D. J. \& White, S. H. 1984: Microstructural and fabric studies from the Moine Nappe, Eriboll, NW Scotland, J. struct. Geol. 6, 369-389.

Friderichsen, J. D., Holdsworth, R. E., Jepsen, H. F. \& Strachan, R. A. 1990: Caledonian and pre-Caledonian geology of Dronning Louise Land, North-East Greenland. Rapp. Gronlands geol. Unders. 148, 133-141.

Gapais, D. 1989: Shear structures within deformed granites: mechanical and thermal indicators. Geology 17, 1144-1147.

Holdsworth, R. E. \& Strachan, R. A. 1991: Interlinked system of ductile strike-slip and thrusting formed by Caledonian sinistral transpression in northeastern Greenland. Geology 19, 510-513.

Jepsen, H. F., Escher, J. C., Friderichsen, J. D. \& Higgins, A. K. 1994: The geology of the north-eastern corner of Greenland photogeological studies and 1993 field work. Rapp. Gronlands geol. Unders 161 (in press).

Kalsbeek, F., Nutman, A. P. \& Taylor, P. N. 1993: Palaeoproterozoic basement province in the Caledonian fold belt of North-East Greenland. Precambrian Res. 63, 163-178. 
Mattauer, M. 1986: Intracontinental subduction, crust-mantle decollement and crustal-stacking wedge in the Himalayas and other collision belts. In Coward, M.P. \& Ries, A.C. (ed.) Collision tectonics. Spec. Publ. geol. Soc. Lond. 19, 37-50.

Oldow, J. S., Bally, A. W., Ave Lallemant, H. G. \& Leeman, W.P. 1989: Phanerozoic evolution of the North American Cordillera. In Bally, A. W. \& Palmer, A. R. (ed.) The geology of North America Vol. A, 139-232. Boulder, Colorado: Geological Socicty of America.

Oldow, J. S., Bally, A. W. \& Ave Lallemant, H. G. 1990: Transpression, orogenic float and lithospheric balance. Geology 18, 991-994.

Robinson, P., Spear, F. S., Schumacher, J. C., Laird, J., Klein, C., Evans, B. W. \& Doolan, B. L. 1982: Phase relations of metamorphic amphiboles: natural occurrence and theory. In Veblen, D. R. \& Ribbe, P. H. (ed.) Amphiboles: petrology and experimental phase relations. Reviews in Mineralogy 9B, 1227., Mineral. Soc. Amer.

Roure, F., Choukroune, P., Berastegui, X., Munoz, J. A., Villien, A., Matheron, P., Bareyt, M., Seguret, M., Camara, P. \& Deramond, J. 1989: ECORS deep seismic data and balanced cross sections: geometric constraints on the evolution of the Pyrenees. Tectonics 8, 41-50.

Sibson, R. H. 1977: Fault rocks and fault mechanisms. J. geol. Soc. Lond. 133, 191-213.

Simpson, C. 1985: Deformation of granitic rocks across the brittle-ductile transition. J. struct. Geol. 7, 503-511.

Spear, F. S. 1980: $\mathrm{NaSi}=\mathrm{CaAl}$ exchange equilibrium between plagioclase and amphibole. An empirical model. Contrib. Mineral. Petrol. 72, 33-41.

Strachan, R. A., Jepsen, H. F. \& Kalsbeek, F. 1991: Regional Caledonian structure of Hertugen af Orléans Land, NorthEast Greenland. Rapp. Gronlands geol. Unders. 152, 95-102. Strachan, R. A., Holdsworth, R. E., Friderichsen, J. D. \& Jepsen, H.F. 1992: Regional Caledonian structure within an oblique convergence zone, Dronning Louise Land, NE Greenland. $J$. geol. Soc. Lond. 149, 359-371.

Sylvester, A. G. 1988: Strike-slip faults. Geol. Soc. Am. Bull. 100, 1666-1703.

Tullis, J. \& Yund, R. A. 1985: Dynamic recrystallization of feldspar: A mechanism for ductile shear zone formation. Geology 13, 238-241. 